\section{Coronavirus y rol de los adenoides}

\section{Coronavirus and the role of adenoids}

Es sabido que el coronavirus afecta muy levemente a los niños pequeños, y los adultos mayores con mayor intensidad y los pacientes mayores de 65 años con alta letalidad. El coronavirus se localiza primero habitualmente en la rinofaringe luego desciende hacia la oro-faringe, tráquea, bronquios y pulmones, a veces con anosmia, con tos seca irritativa, fiebre alta y neumonía bilateral. En su investigación se efectúa el PCR, tomando muestras de rinofaringe para pesquisar los casos positivos y los posibles contactos.

$\mathrm{Al}$ respecto sabemos que los adenoides de la rinofaringe crecen en la niñez, para luego atrofiarse a los catorce o quince años de edad, es decir que estos jugarían un rol importante en protegernos del coronavirus. Algo ya casi olvidado es la poliomielitis aguda viral, al inventar Sabin una vacuna eficaz que casi ha hecho desaparecer este virus en el mundo. Desde el principio del siglo XX, se publicaron trabajos que relataban que los casos más graves de poliomielitis afectaban a los niños adenoidectomizados, terminando con la muerte de algunos de estos niños debido a una poliomielitis bulbar.

Sabin en los años 30' del siglo pasado, efectuó un estudio en monos, a los cuales aplicaba el virus directamente en la rinofaringe. Provocando la muerte de casi todos ellos debido a la poliomielitis bulbar. A otro grupo, les aplicó el virus en las amígdalas faringes, provocando solo una diarrea y quedando estos monos como portadores del virus a través de las heces.
Y es la razón por la que la poliomielitis aparecía en forma de epidemias estivales en algunas regiones de los Estados Unidos.

Por la desaparición mundial de la poliomielitis no se continuó con estos estudios, resultando muy difícil realizar trabajos de setenta u ochenta años atrás. En el año 1953, John Arnold publicó un trabajo titulado "Controversial problems in adenotonsillectomie" , en el que discutía el peligro de la adenodeictomía en niños por la reaparición de la poliomielitis como epidemia.

Según estos estudios, se podría deducir que eliminando directamente el coronavirus en pacientes PCR positivo, aplicando en forma de spray nasal, un viricida que no irrita las mucosas y repetir a los diez días el PCR en estos pacientes positivos y probar la posible efectividad del viricida. Es una hipótesis diagnostica difícil de efectuar; el otro camino es averiguar en los niños infectados, si ellos han sido o no adenoidectomizados. Sería muy difícil, pues los casos severos en niños son escasos y preguntar al epidemiólogo si estos niños habían sido adenoidectomizados antes de enfermarse.

Alejandro Peña M. ${ }^{1}$ ${ }^{1}$ Socio SOCHIORL. Talca, Chile.

\section{Bibliografía}

1. Arnold JW. Controversial problems in adenotonsillectomy. Calif Med. 1953;78(5):444-449.

Correspondencia: 5 Oriente 2249. Talca, Chile. Email: pena.martinez@gmail.com 